\title{
PROSEDUR PENMAPAN DATA KOMPUTER \\ DALAM ANALISIS TEKNOLOGI ALAT BATU
}

Oleh: Agus Soedjono

\section{PENDAHULUAN}

Peran aktif komputer di dalam dunia penelitian arkeologi telah cukup tinggi. Keberhasilan "otak elektronis" tersebut telah terealisasikan pada beberapa hal, baik itu penanganan tahap rencana penelitian, pengolahan data, atau pun penyajian data. Beberapa hasil yang dapat disebut di sini antar lain: keakuratan komputer dalam penyu sunan program rencana penelitian (Khandelwal, 1977), komputer se bagai penyimpan data atau bank data (Harkantiningsih, 1985), komputer berperan dalam pemlotan peta persebaran situs (Chadwick. 1978; Doran dan Hodson. 1975), komputer sebagai pengolah data (gerabah) dan penyajian hasil penelitian (laporan) (Soegondho, 1985).

Telah sepantasnya. komputer dipakai sebagai media bantu penanganan kegiatan arkeologis. Hal ini mengingat kesejajaran antara keterbatasan arkeologi dalam penanganan data dengan kemampuan beragam yang dimiliki komputer itu sendiri. Di satu pihak, arkeologi selalu dihadapkan pada sejumlah besar data, yang memerlukan waktu lama dalam penanganannya. Sedangkan di lain pihak, komputer memiliki sifat kecepatan bekerja dan keakuratan (Lipschutz, 1982: 69), di mana komputer juga dapat melakukan suatu rangkaian panjang dari tugas pengolahan dan analisis data secara otomatis. Hasilnya didapat hanya dengan satu kali tekan tombol (Koentjaraningrat, 1981: 357).

Sebagai satu contoh kasus yang dihadapi arkeologi adalah analisis alat batu, terutama analisis teknologis. Dalam banyak hal, data yang diperoleh darinya secara kuantitatif adalah cukup besar. Sehingga waktu yang diperlukan dalam pengolahan data secara manual sesuai dengan tujuan yang diinginkan cukup lama pula. Dikatakan demikian, karena usaha tersebut pun tidak lepas dari pengamatan beberapa aspek lain yang berkaitan dan mendukungnya. Beberapa aspek tersebut misalnya ciri-ciri teknologis dan tipologis dari data/ sampel yang dianalisis. 
Oleh karena itu, dalam kesempatan ini, contoh kasus di atas akan dipakai sebagai bahan pemikiran, di mana komputer dipakai sebagai media bantu analisis. Secara otomatis, komputer akan lebih efektif dan $e^{f}$ isien dibanding dengan cara yang terdahulu (manual).

Tidak lah berlebihan, bahwa sajian ini tetap berada pada tingkat yang dasar, karena penampilannya lebih dititikberatkan pada prosedur analisis data. Untuk itu, pemikiran-pemikiran lanjutan dari beberapa pihak tetap diperlukan.

\section{KOMPUTER, DATA DAN TEORI}

Komputer dapat digambarkan sebagai suatu mesin elektronik, yang dapat bekerja secara otomatis. Sebuah sistem komputer pada dasarnya terdiri dari tiga bagian, yaitu peralatan komputer yang disebut dengan perangkat keras (hardware), ${ }^{1}$ sistem komputer atau perangkat lunak (software) ${ }^{2}$, dan manusia sebagai pemrogramnya (brainware). Ketiga sarat mutlak itu harus dipenuhi dalam operasional suatu komputer (Soesianto, et. al, 1985: 3-11).

Operasionalisasi komputer dapat berjalan dengan beberapa bahasa yang diperlukan sebagai programnya. Hal ini terlepas dari data yang dimintakan. Macam-macam bahasa program sebagai sarat komunikasi antara lain berupa bahasa BASIC, FORTRAN, COBOL, PASCAL, ALGOL dan lain-lain (Ibid, 1985: 13-15; Soesianto, et.al, 1984: 4-8). Perbedaan mendasar dari masing-masing bahasa program tersebut adalah pada orientasi atau tujuannya. Sedangkan bahasa BASIC dianggap sebagai bahasa yang paling mudah cara pemrogramannya (Soesianto. 1985: Ibid).

Berbeda dengan bahasa-bahasa program di atas, dikenal pula suatu paket program yang telah disiapkan, yaitu berupa serangkaian instruksi yang dirancang untuk memecahkan masalah tertentu. Program tersebut di antaranya berupa paket program pengolah kata WordStar (Naiman, 1985) dan pengolah data, Data Base II (Harkantiningsih, 1985: 6; Soegondho, 1985:9), MINITAB, TSPMINI, TSP, BMD, dan SPSS. Lima buah yang tersebut terakhir lebih sering dipakai untuk pengolahan data dalam sistem informasi statistik (Soe. sianto dan Soeryono, 1981). Perlu diketahui, bahwa di dalam paket program tersebut terdapat bahasa program yang digunakan. Seringkali, bahasa program yang digunakan adalah bahasa FORTRAN. 
Sistem pengolahan data merupakan suatu kesatuan pertgolah data yang terdiri dari peralatan, prosedur, data, dan pengolah data. Sedangkan pengolah data dengan menggunakan alat komputer dapat disebut sebagai sistem pengolah data elektronis (Electronic Data Processing System) (Lipschutz, 1982: 68).

Data yang diperlukan oleh alat elektronis, dapat berupa simbol, kode, huruf, atau pun angka (Koentjaraningrat, 1981: 371). Sehingga dengan demikian, data arkeologi pun dapat dijadikan dalam bermacam bentuk tersebut, sesuai dengan usaha pengolahan data.

Sebelum menginjak bentuk data yang akan disajikan, di bawah ini akan diuraikan beberapa teori mengenai teknologi alat batu, yang menunjang usaha pemasukan data berikut pengolahannya. Proses pembentukan data akan berangkat dari teori yang digunakan. Penjabaran teori tersebut dimodifikasi untuk kemudian dijadikan informasi apa pun bentuknya (angka, kode) sesuai dengan simbol yang diinginkan.

Usaha mengenali teknologi, tidaka lepas dari sifat teknologi itu sendiri. Teknologi alat batu sebagai teknologi reduktif atau subtraktif,secara mudah dikenali kembali melalui pengamatan serpihan/tatal sebagai hasil reduksinya (Crabtree, 1972; Deetz, 1967). Pengamatan tersebut ditujukan pada beberapa ciri teknologi atau atribut dari tatal tersebut. Ciri-ciri teknologis tersebut antara lain: ${ }^{3}$ dataran pukul (Striking Platform), bibir (Lip), kerucut pukul (Bulb of Percussion), gelombang serpih (Ripple) (Crabtree, 1972:44; Oakley, 1976: 10), kulit batu (cortex), ukuran (panjang, lebar, tebal) dan morfologi (Speth, 1977).

1. Dataran pukul. Disebut demikian karena bentuknyayang datar, terletak di pangkal, sebagai daerah atau bidang tempat penyerpihan dilakukan (Crabtree, 1972:84). Dalam ragamnya, dataran pukul ini ada yang berfaset dan ada yang tidak. Sedangkan variasi ukuran yang dimiliki dataran pukul adalah sempit ( tebal serpih), sedang (= tebal serpih) dan lebar ( tebal serpih).

2. Bibir. Pengertian ini menunjuk pada satu ciri pada bagian sisi tepi dataran pukul, yang menjorok ke luar pada bagian ventral serpih. Dengan kata lain, bahwa hadirnya bibir ini memberi kesan sebagai sudut batas antara dataran pukul dengan bidang ventral. Kehadiran atribut ini diduga sebagai akibat penggunaan alat pukul yang lunak (soft. hammeer percussion or pressure) (Ibid, 1972:84). 
3. Kerucut pukul. Atribut ini berada pada bidang ventral, dengan bentuk cembung atau kerucut. Atribut tersebut terletak di bawah bibir. Kehadiran atribut ini biasanya merupakan akibat dari penerapan atau kekuatan penekanan dan pemukulan (Ibid, 1972: 48). Atribut ini juga dapat menandai sifat dari batuan silika (Pettijohn. 1975).

4. Tatu serpih. Atribut ini berupa pecahan atau luka, yang terletak pada kerucut pukul. Kehadiran ciri ini diduga berkaitan dengan saat pernangkasan pada dataran pukulnya melalui bantuan alat yang lunak (Subagus, 1981: 4). Dalam ragamnya, tata serpih memiliki bentuk memanjang (luka panjang vertikal), melebar (luka panjang horisontal) dan simetris.

5. Kerut serpih. Atribut ini berupa garis-baris yang berkerut, terdapat pada bidang ventral. Diduga, hadirnya atribut ini akibat dari teknik pemukulan yang diterapkan saat melepaskan serpihan (Crabtree, 1972: 64).

6. Gelombang serpih. Istilah ini menunjuk pada suatu ciri yang berbentuk gelombang-gelombang berkerut, yang terdapat pada bidang ventral. Atribut yang biasanya terletak di bawah kerucut pukul ini akan terlihat hanya pada jenis batuan yang kompak atau silika (Ibid, 1972: 89).

7. Kulit batu. Hadirnya kulit batu ini selalu dikaitkan dengan awal terlepasnya serpihan dari suatu bahan dasar (raw materia).

8. Faset. Adalah sebuah ciri yang diidentikkan dengan "bulbus cekung" (Ibid, 1972: 48) akibat dari pangkasan pembentukan yang sering dijumpai pada bidang dorsal.

9. Ukuran. Atribut ini tidak dapat lepas dari sifat bahan batuan dan gaya atau tekanan yang dipukulkan untuk menghasilkan serpihan (Speth, 1977).

10. Morfologi. Kehadiran bentuk bentuk serpihan juga tidak lepas dari aspek sifat batuan, besarnya bahan dasar, titik pemukulan, dan sudut pemukulan (Ibid, 1977).

\section{PROSEDUR ANALISIS}

Pengertian-pengertian sebagai penjabaran teori di atas, akan dipakai sebagai landasan hipotesis serta sebagai titik tolak pengamatan sampel tatal. Di lain pihak, komputer memerlukan instruksi- 
Instruksi sebagai masukannya guna pengolahan data (Koentjaraningrat. 1981: 364). Teori sebagai instruksi yang harus dimasukkan ke dalam komputer, lebih mudah diartikan merupakan koding data. Dengan kata lain, pengamatan data atau sampel tersebut tetap berdasarkan teori yang digunakan.

Bentukan data dalam koding tersebut dapat berupa angka atau kode yang telah ditentukan. Perian data berikut kode yang digunakan adalah identik dengan koding data respons terhadap pertanyaan tertutup. Dengan pengertian, bahwa nomor kode untuk karakter dari variabel yang ditampilkan berupa jawaban mutlak (Ibid, 1981: $380-382$ ).

Suatu contoh pembuatan nomor kode, dengan beberapa variabel sebagai satuan ciri yang diamati sebagai berikut:

Nomor Kode Analisis. Data Tatal Batu

\begin{tabular}{|c|c|c|c|}
\hline No. & Variable/Atribut & No. Kode & Keterangan \\
\hline & Dataran pukul & $\begin{array}{l}1 \\
2\end{array}$ & $\begin{array}{l}\text { ada } \\
\text { tidak ada }\end{array}$ \\
\hline 2. & Keadaan dataran pukul & $\begin{array}{l}1 \\
2\end{array}$ & $\begin{array}{l}\text { berfaset } \\
\text { tidak berfaset }\end{array}$ \\
\hline & Ukuran dataran pukul & $\begin{array}{l}1 \\
2 \\
3\end{array}$ & $\begin{array}{l}\text { sempit } \\
\text { sedang } \\
\text { lebar }\end{array}$ \\
\hline & Tatu serpih & $\begin{array}{l}1 \\
2\end{array}$ & $\begin{array}{l}\text { ada } \\
\text { tidak ada }\end{array}$ \\
\hline & Ukuran tatu serpih & $\begin{array}{l}1 \\
2 \\
3\end{array}$ & $\begin{array}{l}\text { memanjang } \\
\text { melebar } \\
\text { simetris }\end{array}$ \\
\hline & Kerucut pukul & $\begin{array}{l}1 \\
2\end{array}$ & $\begin{array}{l}\text { ada } \\
\text { tidak ada }\end{array}$ \\
\hline & Bibir & $\begin{array}{l}1 \\
2\end{array}$ & $\begin{array}{l}\text { ada } \\
\text { tidak ada }\end{array}$ \\
\hline & Kerut serpih & $\begin{array}{l}1 \\
2\end{array}$ & $\begin{array}{l}\text { ada } \\
\text { tidak ada }\end{array}$ \\
\hline
\end{tabular}



9 Gelombang serpih
10. Kulit batu
11. Faset
12. Ukuran panjang ${ }^{4}$
13. Ukuran lebar
14. Ukuran tebal'
15. Morfologi?

Dan seterusnya
1 ada

2 tidak ada

1 ada

2 tidak ada Ukuran / Jumlah angka mutlak angka mutlak angka mutlak

1 bentuk 1
2 bentuk 2
$3 \quad$ bentuk 3 dan seterusnya.

Setelah dilakukan penentuan variabel/atribut yang akan diamati dan diukur. maka tahapan selanjutnya adalah usaha mengenali beberapa variabel tersebut dari sejumlah sampel yang dianalisis. Dapat dijelaskan, bahwa satu sampel akan memiliki kurang lebih 15 buah atribut.

Pengamatan berikut pengukuran sampel tersebut akan dimasukkan ke dalam kartu tabulasi ${ }^{\gamma}$. Proses ini lebih diartikan dengan pemindahan data verbal ke dalam data statistik. ${ }^{9}$ Koding data ke dalam sebuah kartu tabulasi dilakukan secara manual.

Proses selanjutnya adalah pemasukan data statistik (dari kartu tabulasi) ke dalam komputer. Pemasukan data tersebut dapat dibantu secara mudah dan cepat dengan menggunakan paket program WordStar. Kemampuan besar dari paket program pengolah kata tersebut antara lain: a. memperbaiki kata yang terletak di bagian manapun dalam sekejap. b. memindahkan suatu bagian naskah dari tempat yang satu ke tempat lain (dan mengembalikannya ke posisi semula, jika diinginkan). c. menemukan posisi selanjutnya (sebelumnya) suatu kata atau suatu bagian kalimat di tengah naskah. d. menyimpan sejumlah blok naskah dan mencetaknya dalam berbagai kombinasi (Naiman, 1985: 3).

Sedangkan pengolahan data dapat dilakukan dengan menggunakan banyak cara. Bahasa program atau paket program dapat dipakai sesuai dengan tujuan analisis data. Pengolahan data dengan 
bahasa program (non paket) berarti pengolah data mencetak sendiri instruks-instruksi di dalam pemrograman. Sedangkan paket program telah menyediakan beberapa macam instruksi untuk pemecahan masalah. Untuk pengolahan data dalam sistem informasi statistik, paket program yang dapat digunakan, antara lain seperti MINITAB, TSPMINI, TSP, BMD, dan SPSS (Soesianto dan Soeryono, 1981). Paket yang disebut terakhir sering digunakan dalam pemecahan ilmuilmu sosial.

Besarnya kemampuan paket-paket program tersebut tidak dapat disebutkan secara terinci, hanya sebagian dari sebagian kecil yang dapat dilakukan (terutama dalam kaitan dengan sampel tatal di atas) antara lain: penghitungan frekuensi, pencarian korelasi (antar atribut), analisis cluster, dan sebagainya.

\section{PENUTUP}

Akhir dari sajian ini akan diberikan beberapa ulasan singkat.antara kesejajaran komputer dan arkeologi. Komputer dengan kemampuan yang canggih dapat bekerja dengan cepat, teliti, dan obyektif. Di lain pihak, arkeologi diharapkan pada sejumlah besar data yang kerap kali sulit ditangani secara manual.

Peranserta komputer di dalam penanganan data arkeologi, tidak lah berarti cara manual dapat ditinggalkan. Cara tersebut masih diperlukan ddalam koding data secara statistik, yaitu pemindahan data verbal ke dalam data statistik pada kartu tabulasi yang telah disiapkan.

Beranjak dari tahap itu, dalam pengolahan data selanjutnya komputer dapat meninggalkan cara manual. Pada tahap olah data ini kemampuan komputer diperanaktifkan. Namun demikian, pengolah data (brainware) harus dapat berkomunikasi secara aktif dengan alat elektronis tersebut. Bahasa sebagai sarat komunikasi dapat ditentukan sendiri dengan menggunakan bahasa program atau pun dengan paket program yang telah disiapkan tanpa menciptakan instruksi-instruksi untuk pemecahan masalah.

Bahasa ataupun paket program dapat digunakan sesuai dengan kebutuhan analisis. Walaupun demikian, tidak lah harus diartikan "siap pakai dan siap analisis". Pengolah data (dengan bahasa programnya) harus memutar-balikkan otak guna penyusunan instruksiinstruksi pengolahan data. Hal ini mengingat bahwa karakteristik data 
tentunya memunculkan instruksi-instruksi yang khas pula dalam pengolahannya (tidak lepas dari analisis yang diharapkan).

\section{Catatan}

1. Yang dimaksud dengan perangkat keras (hardware) adalah ujud fisis dari piranti komputer beserta seluruh pir anti perlengkapannya. Piranti kompu ter ini antara lain terdiri dari: a. piranti Input dan Output. b. Unit Pengolah Utama (CP(J). c. Piranti perekam atau penyimpan data. d. Pi ranti untuk komunikasi. e. Piranti-piranti yang lain.

2. Yang dimaksud dengan perangkat lunak (software) adalah fasilitas yang digunakan untuk mengendalikan aktifitas seluruh piranti komputer. Software biasanya berupa suatı program. Adapun fasilitas darinya antara lain: a. Application Software yang terdiri dari seluruh prosedur pengelolaan informasi termasuk rancangan sistem informasi, petunjuk pelaksanaan dan aturan-aturan yang lain. di mana bertujuan menunjang kemudahan para pemakai. b. Operating System adalah fasilitas yang memungkinkan komputer mengelola dirinya sendiri dengan seefesien mungkin, di mana bertujuan mengoptimalkan sumber daya mesin komputer yang ada.

3. Periksa gambar 1 .

4. Cara pengukuran terhadap atribut ini dapat dilihat pada gambar 2 .

5. Cara pengukuran terhadap atribut ini dapat dilihat pada gambar 2 .

6. Cara pengukuran terhadap atribut ini dapat dilihat pada gambar 2 .

7. Morfologi umum dari tatal/serpihan dapat dilakukan secara klasifikasi tipologi.

8. Periksa contoh kartu tabulasi; kartu ini memiliki atau dapat mengandung sejumlah besar variabel/atribut. Nomor yang diberikan padanya adalah sesuai dengan nomor kode analisis (periksa nomor kode analisis). Kartu yang dipakai tersebut mengambil contoh dari "Penyusunan Buku Kode dan Mengkode Data", Metode Penelitian Survei. Oleh Tukiran, Tri Handayani dan Peter Hagul.

9. Statistik tidak hanya diartikan sekumpulan angka yang menerangkan sesuatu dalam bentuk daftar dan grafik, tetapi juga diartikan cara-cara mengenai pengumpulan data, penganalisaan dan interpretasi yang berbentuk angka-angka. Selain itu, pengertian statistik adalah bilanganbilangan yang dapat menerangkan sifat dari sekumpulan data (Amudi Pasaribu. Pengantar Statistik. 1975. hal. 17-19). 


\section{DAFTAR PUSTAKA}

Chadwick. A.J. 1978. A Computer Simulation of Mycenaean Settlement". Simulation Studies in Archaeology. London: Cambridge University Press. hal. 47 $-58$.

Crabtree. Don E. 1972. An Introduction to Flintworking. Idaho : Occasional Papers of the Museum Idaho State University.

Deetz, James F. 1967. Invitation to Archaeology. New York: National History Press.

Doran, J.E. and FR. Hodson. 1975. Mathematics and Computer in Archaeology. Edinburgh University Press.

Harkantiningsih, M .Th .N. 1985. "Penggunaan Komputer Sebagai Alat Penyimpan Data", REHPA JI. Pandeglang (kertas kerja).

Khandelwal, V.K and Mulyono S.1976. Computerized Stone Registration System for the Restoration of Candi Borobudur". Pelita Borobudur. Seri B, No. 8. Laporan Kegiatan Proyek Pemugaran Candi Borobudur.

Koentjaraningrat, 1981. "Koding Data Untuk Komputer", Metode-Metode Penelitian Masyarakat. Gramedia. Jakarta. hal. 357 - 388.

Lipschutz. M.M. and Seymour L. 1982. Theory and Problems of Data Processing. Singapore: Asian Student Edition First Impression, June.

Naiman, A. 1985. Pengantar WordStar. alih bahasa: Ir. Oei Bong Liem, edisi ke 2. Penerbit Indomicros.

Oakley, Kenneth P. 1976. Man The Tool Maker. Chicago: The University of Chicago Press.

Pasaribut, Amudi. 1964. Pengantar Statistik. Jilid I. Universitas Nommensen.

Pettyjohn, F.J. 1975. Sedimentary Rock Harper and Row Publishing Company. New York.

Soegondho. S. 1985. "Komputer Untuk Penelitian Arkeologi", REHPA II, Pandeglang (kertas kerja).

Soesianto, F. dan Eko Nugroho, 1984. Belajar Sendiri Bahasa Fortran. Andi Offset. Yogyakarta.

\section{Berkala Arkeologi VII (1)}


Soesianto. F.. Eko Nugroho. Insap Santoso.1985. Pemrograman Basic. Andi Offset. Yogyakarta.

Soesianto. F dan Soeryono. Te'kniks Pengolahan Data Statistik: Pende'katan Algoritmis. 1981 (belum terbit)

Speth John D. "Experimental Investigation of Hard Hammer Percussion Flaking". Experimental Archa'ology. Ne'w York: Columbia University Pre'ss. 1977 hal. 3- 37.

Tukiran. Tri Handayani dan Peter Hagul. "Peenyusunan Buku Kode' dan Mengkode' Data Metode' Penelitian Survei. LP3ES. 1984. cetakan ke' 4. hal. 169-190)

Bidang

Dorsal

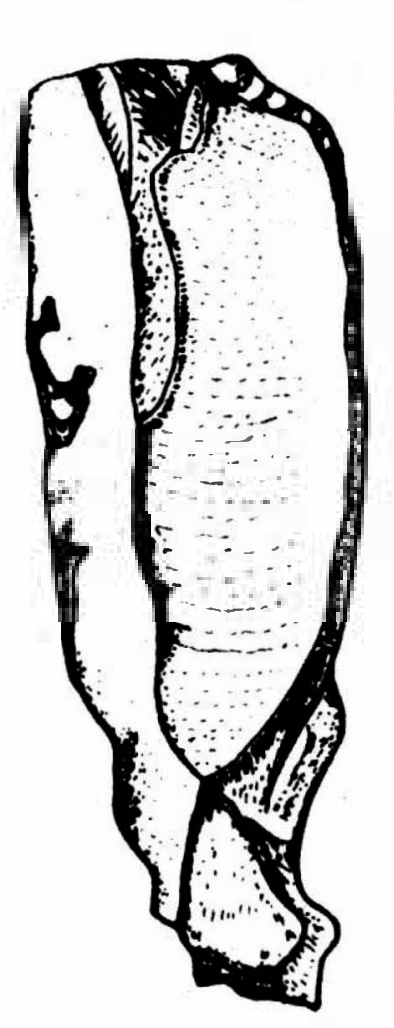

Bidang

Ventral

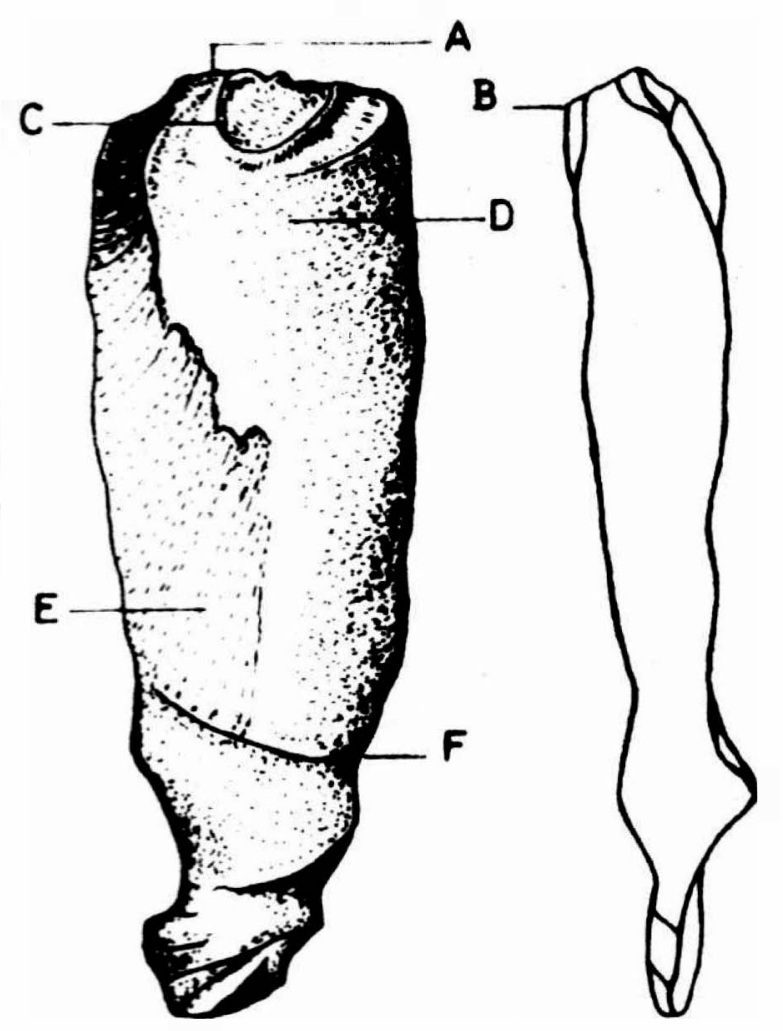

Keterangan:

A. Dataran pukul (Striking Platform)

B. Bibir (Lip)

C. Tatu serpih (Bulbar Scar)

D. Kerucut pukul (Bulb of Percussion)

E. Alur (= kerut) Serpih (Fissures).

F. Gelombang Serpih (Ripples).

Gambar 1: Serpihan dengan ciri-ciri teknologis. 

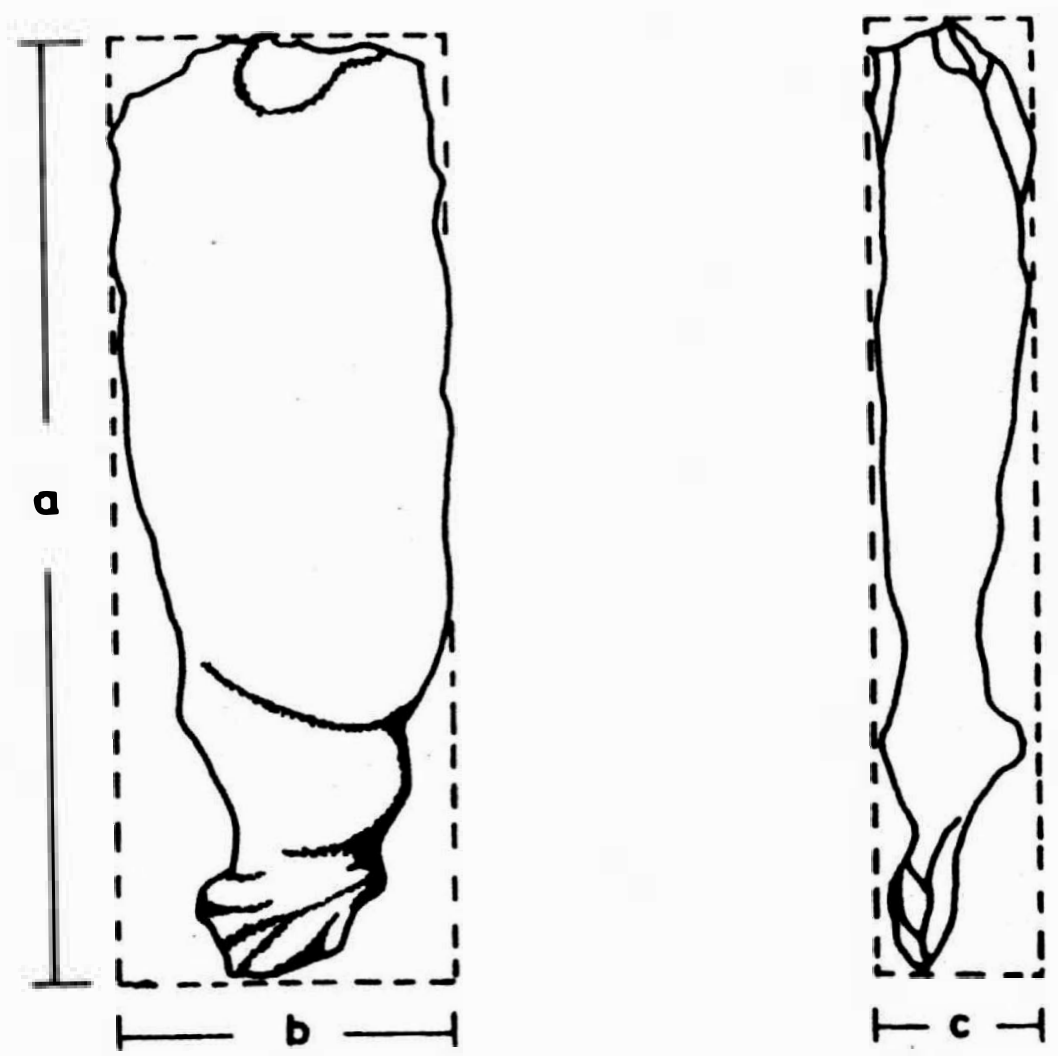

Keterangan:

$$
\begin{aligned}
& a \text { - ukuran panjang } \\
& b \text { - ukuran lebar } \\
& c \text { - ukuran tebal }
\end{aligned}
$$

Gambar 2: Pengukuran serpihan/tatal 


\section{Contoh Kartu Tabulasi}

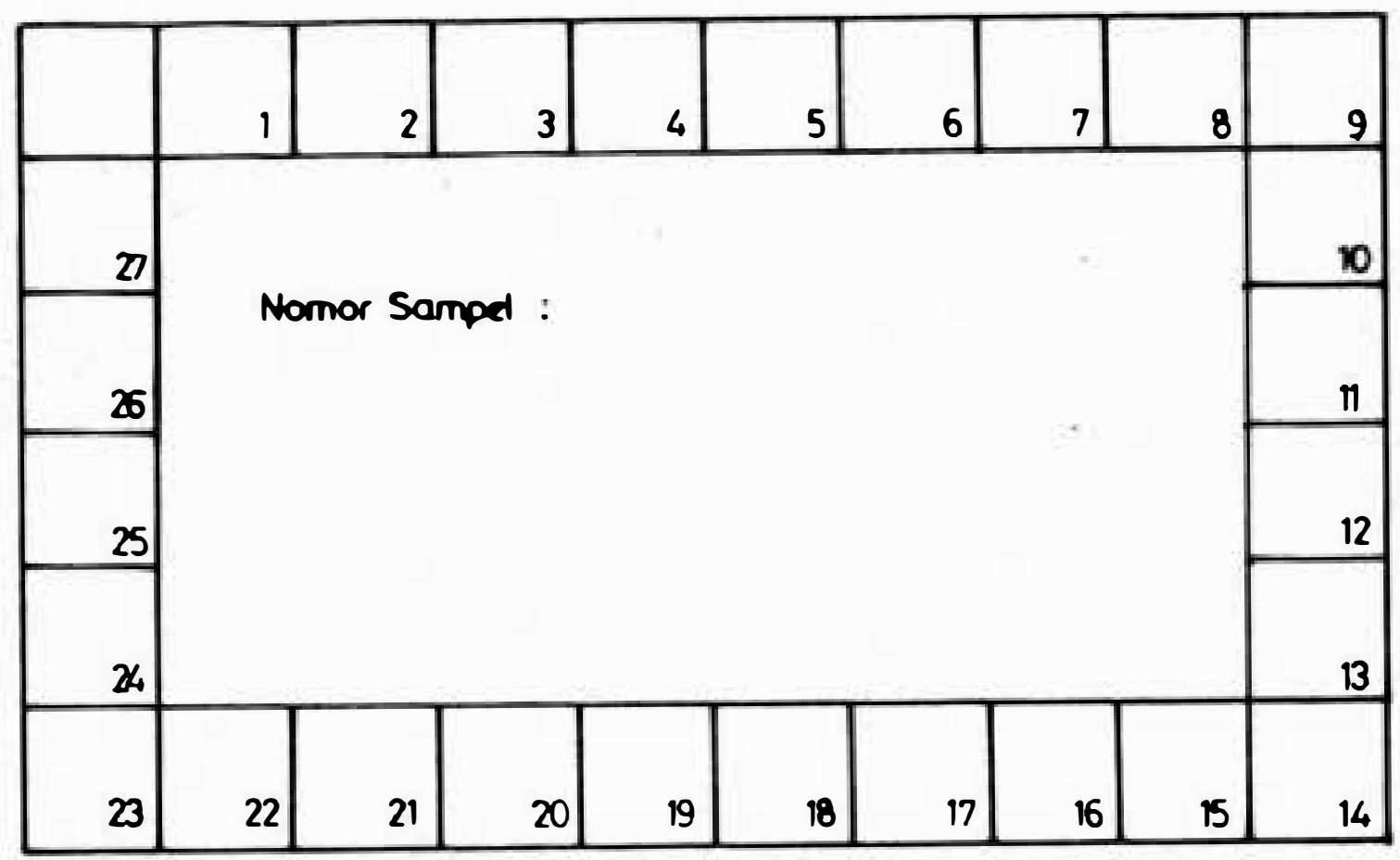

\section{KETERANGAN:}

Kotak 1 berisi variabel/atribut no. 1 Dataran pukul

Kotak 2 berisi variabel/atribut no. 2 : Keadaan dataran pukul

Kotak 3 berisi variabel/atribut no. 3 : Ukuran dataran pukul

Kotak 4 berisi variabel/atribut no. 4 Tatu serpih

Kotak 5 berisi variabel/atribut no. 5 . Ukuran tatu serpih

Kotak 6 berisi variabel/atribut no. 6 Kerucut pukul

Kotak 7 berisi variabel/atribut no. 7 : Bibir.

Dan seterusnya. 